\title{
Analisa Nilai Valuasi Startup Berdasarkan Faktor Keuangan Dan Faktor Non Keuangan Media Online PT. XYZ Bali
}

\author{
Ni Luh putu Agustini ${ }^{1}$, Putu Agus Swastika M.Kom², Ni Made Estiyanti S.E,M.Si., Ak ${ }^{3}$ \\ STMIK Primakara \\ Denpasar, Indonesia \\ e-mail: putuagustininiluh@gmail.com ${ }^{1}$, masagusswastika@gmail.com², \\ estiyanti@primakara.ac.id ${ }^{3}$
}

\begin{abstract}
Abstrak
Jumlah pengguna internet di Indonesia meningkat dengan sangat pesat dalam dua dekade ini. Perkembangan teknologi beriringan dengan pertumbuhan perusahaan perintis atau startups,baik yang mengalami kegagalan maupun kesuksesan besar. Penggalangan dana adalah sumber kehidupan startup, aliran dana yang stabil dari berbagai sumber akan sangat membantu perusahaan.Keberhasilan startup, salah satunya dapat dilihat dari seberapa besar nilai valuasinya, semakin besar nilainya maka kesempatan untuk mendapatkan dana investor terbuka lebar. PT. XYZ merupakan salah satu startup mediaonline di Indonesia dan yang pertama di Bali, dana investasi tentu dapat menunjang dan mengoptimalkan perkembangan perusahaan. Mengingat pentingnya dana investasi untuk kelangsungan perusahaan, maka perhitungan valuasi diperlukan untuk mendapatkan kesempatan menerima pendanaan. Elemen-elemen penting perusahaan, baik dari segi keuangan maupun non keuangan, akan menjadi daya tarik investor untuk menanamkan modalnya
\end{abstract}

Keywords- : Valuasi, Startup, Investasi

\begin{abstract}
The number of internet users in Indonesia has increased rapidly in the past two decades. Technological developments coincided with the growth of pioneering companies or startups, both failures or great successes. Fundraising is the lifeblood of startup, a steady stream of funds from various sources will greatly help the company. The success of startups, one of them can be seen from how much the value of the startup's valuation. The greater the value then the opportunity to get investors' funds wide open. PT. XYZ is one of the startup of online media in Indonesia and the first in Bali, investment funds can certainly support and optimize the development of the company. Considering the importance of investment funds for the sustainability of the company, a valuation calculation is needed to gain an opportunity to receive funding. The important elements of the company, both in terms of financial and non-financial, will be the attraction of investors to invest.
\end{abstract}

Keywords : Valuation, Startup, Investment

\section{PENDAHULUAN}

Startup identik dengan perusahaan kecil yang memiliki ide inovatif dan lekat dengan istilah entrepreneur. Salah satu pakar dalam bidang kewirausahaan Steve G. Blank mendefinisikan startup adalah "an organization formed to search for a repeatable and scalable business model". Artinya startup adalah sebuah organisasi temporer yang digunakan untuk mencari bisnis model berulang dan dapat dikembangkan menjadi besar. 
PT. XYZ merupakan salah satu bagian dari perusahaan startup media online Indonesia dan yang pertama di Bali. Perkembangan internet telah mendorong cepatnya arus informasi yang tersebar di dunia maya. Media online akan menjadi pilihan masyarakat saat ini untuk update informasi daripada melalui media cetak. Dalam [1] menyebutkan jenis konten internet yang diakses pengguna internet adalah konten berita sebesar 96,4\% yaitu 127,9 juta orang, tentunya ini merupakan pasar potensial bagi industri media online baik yang baru memulai usaha maupun yang sudah berjalan. Startup XYZ sejak tahun 2008 hadir untuk memenuhi kebutuhan informasi atau peristiwa terkini dan terhangat yang ada di Bali, mulai dari peristiwa penting, menarik, unik,dan inspiratif.

Startup XYZ tentunya membutuhkan dana investor untuk memperkuat pertumbuhan perusahaannya. Nilai valuasi perusahaan tentunya menjadi daya tarik bagi investor untuk menanamkan modalnya. Berdasarkan hal tersebut untuk menganalisa valuasi nilai perusahaan startup Startup XYZ yang sebagian besar asetnya merupakan asset tak berwujud, penulis akan melakukan perhitungan nilai perusahaan Startup XYZ dengan menggunakan Metode Scorecard Valuation yang merupakan suatu metode untuk membandingkan perusaaan sejenis pada tahap perkembangan yang sama (pre-revenue perusahaan startups). Tahap pertama dalam metode ini adalah menentukan nilai rata-rata valuasi (pre-money valuation) perusahaan sejenis. Tahap selanjutnya menggunakan metode Scorecard, dengan mengalikan bobot maksimal setiap indikator dengan kisaran ranking (1) sampai dengan 7 (ranking bisa menggunakan Skala Likert dari kuesioner (valuation worksheet) setiap indikator) beberapa perusahaan sejenis, dengan kriteria bobot tertentu. Maka penulis mengambil judul "Analisa Nilai Valuasi Startup Berdasarkan Faktor Keuangan dan Non

\section{Keuangan Studi Kasus Perusahaan Startup} XYZ”, sehingga diharapkan kedepannya penelitian ini dapat memudahkan bertemunya Startup XYZ dengan investor.

Berdasarkan uraian latar belakang yang dipaparkan diatas dapat dirumuskan beberapa permasalahan sebagai berikut : (1) Faktorfaktor yang mempengaruhi nilai valuasi Startup XYZ? (2) Bagaimana menghitung nilai valuasi Startup XYZ berdasarkan factor keuangan dan factor non keuangan?

\section{KAJIAN PUSTAKA 2.1 Pengertian Media Online}

Dalam [3] menurut Asep Syamsul M. Romli media online (online media) adalah media massa yang tersaji secara online di situs web (website) internet.

\section{Karakteristik Media Online}

Dalam [3] karakteristik dan keunggualn media online dibandingkan "media konvensional" (cetak) antara lain :

a) Kapasitas luas. Halaman web bisa menampung naskah sangat panjang.

b) Pemuatan dan editing naskah bisa kapan saja dan dimana saja.

c) Jadwal terbit bisa kapan saja, bisa setiap saat.

d) Cepat, begitu di-upload langsung bisa diakses semua orang.

e) Menjangkau seluruh dunia yang memiliki akses internet.

f) Aktual, berisi info aktual karena kemudahan dan kecepatan penyajian.

g) Update, pembaruan informasi terus dan dapat dilakukan kapan saja.

h) Interaktif

\subsection{Pengertian StartUp}

Dalam [5] menurut Paul Graham startup merupakan sebuah perusahaan yang didesain untuk berkembang dengan cepat. Startup tidak harus bergerak di bidang teknologi, memperoleh dana dari investor dan melakukan exit. 
Dalam [5] startup is a company designed to grow fast. Sedangkan dalam [6] Startup is a human institution design that create something new under condition extreme and serenity. It doesn't say about what size of the company or what sector of industry, it just says we're trying to do institution building when we don't know what we don't know.

Jadi kesimpulannya, startup adalah suatu bisnis yang baru dirintis, masih berada di posisi yang serba tidak pasti, dan masih berada di fase pengembangan untuk menjadi perusahaan besar.

\subsection{Nilai Perusahaan (valuasi)}

Dalam [4] Definisi nilai perusahaan adalah : "Nilai perusahaan merupakan harga yang bersedia dibayar oleh calon pembeli apabila perusahaan tersebut dijual, semakin tinggi nilai perusahaan semakin besar kemakmuran yang akan diterima oleh pemilik perusahaan."

\section{Valuasi StartUp}

Dalam [5] valuasi Startup adalah nilai ekonomi dari sebuah bisnis. Niali valuasi bisa digunakan sebagai acuan untuk mengukur seberapa besar potensi sebuah bisnis. Parameter yang digunakan untuk menentukan nilai valuasi startup, yaitu:
a) Jumlah dan nominal transaksi
b) Jumlah pengguna
c) Teknologi produk
d) Kualitas tim
e) Kompetitor

\subsection{Faktor-faktor Penentu Nilai Valuasi Startup}

Faktor - Faktor Penentu Nilai Valuasi Startup

Salah satu hal yang tidak luput dari sebuah startup adalah nilai valuasi. Ada 5 faktor yang mempengaruhi nilai valuasi startup seperti yang di kutip dari situs techinasia sebagaimana dalam situs (https://id.techinasia.com/faktorpenentu-valuasi-startup), factor tersebut adalah indikator umum yang bisa menjadi acuan untuk menentukan nilai valuasi sebuah startup. (Perlu digarisbawahi bahwa nilai valuasi bukanlah angka sebenarnya dari startup Anda. Nilai itu hanyalah indikator bagi para $\mathrm{VC}$ yang ingin memberikan investasi ke sebuah startup).

\section{Traksi}

Traksi merupakan salah satu kunci utama yang dapat menarik perhatian investor. Salah satu alasan kenapa sebuah startup masih eksis dalam jangka waktu panjang adalah jumlah pengguna. Bagaimanapun, jumlah pengguna bukanlah satu-satunya jenis traksi yang bisa dijadikan acuan. Traksi bisa juga dilihat dari keuntungan, pendapatan, pageview, jumlah transaksi, dan lainnya tergantung jenis bisnis Anda. Jadi apabila Anda ingin menggalang pendanaan dengan jumlah yang besar, pastikan startup Anda memiliki traksi yang dapat menarik perhatian investor.

2. Reputasi Tim

Founder dan tim yang dimiliki sebuah startup sangat menentukan nilai valuasi. Karena hal ini merupakan salah satu acuan bagi investor untuk mengetahui apakah startup itu dikelola oleh yang benar, punya masa depan, dan bisa bersaing dengan kompetitor lain.

Apabila Anda perhatikan tren startup di Indonesia yang mendapatkan investasi, sebagian besar founder-nya memiliki latar belakang akademik dari perguruan tinggi di luar negeri. Tapi bukan berarti hanya founder yang menempuh pendidikan di luar negeri saja yang berkesempatan mendapat pendanaan. Masih banyak startup lokal yang memiliki founder lulusan dalam negeri seperti William Tanuwijaya, pendiri Tokopedia. Dengan kegigihannya, kini Tokopedia menjadi startup lokal yang mendapat pendanaan paling besar

3. Revenue

Revenue merupakan faktor yang paling gampang untuk menentukan nilai valuasi. Namun, bagi startup tahap awal, akan lebih baik untuk fokus terhadap jumlah pengguna 
dibandingkan dengan jumlah revenue. Karena apabila mengenakan biaya yang tinggi, maka kemungkinan besar akan memperlambat pertumbuhan pengguna.

Hal ini mungkin bertolak belakang dengan intuisi Anda yang mungkin beranggapan bahwa dengan memiliki revenue, maka sebuah startup sudah memiliki profit yang sebenarnya. Padahal, tujuan startup bukan hanya untuk memperoleh uang, namun yang lebih penting adalah berkembang dengan cepat sembari memperoleh pendapatan. Apabila sebuah startup tidak berkembang dengan cepat, maka sama saja dengan bisnis tradisional yang hanya mementingkan pendapatan.

\section{Jangkauan distribusi}

Walaupun masih dalam tahap awal, startup Anda setidaknya harus sudah memiliki jangkauan distribusi. Hal ini akan menjadi salah satu acuan bagi para investor untuk mengetahui akan menjadi seperti apa startup Anda ke depannya.

\section{Kondisi Sektor}

Investor biasanya tidak hanya fokus berinvestasi di satu negara saja. Mereka akan bepergian dari satu negara ke negara lain untuk mencari startup yang tepat untuk diinvestasi, khususnya di negara-negara berkembang di Asia Tenggara seperti Indonesia. Kawasan ini memiliki jumlah penduduk yang besar, pengguna internet yang semakin meningkat, dan pertumbuhan kelas menengah yang pesat.

\section{Tipe Artikel}

Artikel ini merupakan artikel hasil penelitian. Dimana penelitian ini dilaksanakan di PT. XYZ, Tohpati, Denpasar,Bali.

Lokasi penelitian ini dilakukan di PT. XYZ, Tohpati, Denpasar,Bali.

\section{HASIL DAN PEMBAHASAN}

1. Analisa Keuangan

1) Analisa Komparatif Laporan Laba Rugi
Sumber data yang dimaksud yaitu:

1. 1.Data Primer, merupakan data yang diperoleh secara langsung dari objek yang diteliti baik dari pribadi (responden) maupun dari suatu perusahaan yang mengolah data untuk keperluan penelitian,. Contohnya : wawancara tentang riwayat pendidikan, pengalaman kerja

2. Data Sekunder, yaitu data yang diperoleh atau dikumpulkan oleh peneliti dari berbagai sumber yang dapat menunjang data primer. Dalam penelitian ini adalah hasil studi dari literatur buku, jurnal, artikel serta beberapa situs di internet yang dapat menunjang proses penelitian. Contoh data ini adalah sejarah perusahaan, visi dan misi, struktur organisasi serta data keuangan.

analisis yang digunakan dalam penelitian ini yaitu analisis deskriptif kuantitatif dan kualitatif. Metode ini dilakukan dengan cara analisis data kuantitatif yang termasuk di dalamnya analisis laporan keuangan komparatif yakni penelaahan perubahan saldo tiap-tiap akun dari tahun ke tahun atau selama beberapa tahun, analisis rasio untuk mengetahui kondisi keuangan perusahaan diantaranya rasio likuiditas, aktifitas dan profitabilitas, analisis scalling stage yaitu metode analisis untuk perusahaan startup yang telah memiliki pendapatan serta projeksi keuangan perusahaan.

Kemudian analisis data kualitatif dilakukan dengan metode scorecard valuation, metode ini digunakan untuk membandingkan perusaaan sejenis pada tahap perkembangan yang sama (pre-revenue perusahaan startups). https://goo.gl/UYDZyy 
Tabel 1. Analisa Komparatif Laporan Laba Rugi PT.XYZ Tahun 2014-2016

\begin{tabular}{|c|c|c|c|c|}
\hline \multirow{3}{*}{ Pendapatan Jasa } & 2016 & 2015 & 2014 & $\begin{array}{l}\text { Pres } \\
\text { enta } \\
\text { se }\end{array}$ \\
\hline & $\begin{array}{c}\mathrm{Rp} \\
113,900,000.0\end{array}$ & $\mathrm{Rp}$ & $\mathrm{Rp}$ & \\
\hline & 0 & $67,560,000.00$ & $41,230,000.00$ & $40 \%$ \\
\hline Pendapatan & $\mathrm{Rp}$ & $\mathrm{Rp}$ & $\mathrm{Rp}$ & 1,4 \\
\hline Diluar Usaha & $625,000.00$ & $102,432.00$ & $46,436.00$ & $\%$ \\
\hline Laba Kotor & $\begin{array}{c}\mathrm{Rp} \\
114,525,000.0 \\
0\end{array}$ & $\underset{67,662,432.00}{\mathrm{Rp}}$ & $\underset{41,276,436.00}{\mathrm{Rp}}$ & $40 \%$ \\
\hline \multicolumn{5}{|l|}{ Beban Usaha: } \\
\hline Administrasi \& & $\mathrm{Rp}$ & $\mathrm{Rp}$ & $\mathrm{Rp}$ & - \\
\hline Umum & $3,953,500.00$ & $7,460,305.00$ & $14,629,875.00$ & $35 \%$ \\
\hline Biaya Gaji & $\mathrm{Rp}$ & $\mathrm{Rp}$ & $\mathrm{Rp}$ & \\
\hline Pegawai & $61,050,000.00$ & $36,200,000.00$ & $17,400,000.00$ & $52 \%$ \\
\hline Biaya & $\mathrm{Rp}$ & $\mathrm{Rp}$ & $\mathrm{Rp}$ & \\
\hline $\begin{array}{c}\text { Surat/Materai } \\
\text { Biaya }\end{array}$ & $681,500.00$ & $375,500.00$ & $140,000.00$ & $69 \%$ \\
\hline Administrasi & $\mathrm{Rp}$ & $\mathrm{Rp}$ & $\mathrm{Rp}$ & \\
\hline Bank & $401,200.00$ & $298,830.00$ & $249,382.00$ & $17 \%$ \\
\hline Biaya Alat Tulis & $\mathrm{Rp}$ & $\mathrm{Rp}$ & $\mathrm{Rp}$ & - \\
\hline Kantor & $707,000.00$ & $2,184,390.00$ & $2,184,390.00$ & $31 \%$ \\
\hline \multicolumn{5}{|l|}{ Biaya Peralatan } \\
\hline \multicolumn{5}{|l|}{ Biaya } \\
\hline Penyusutan & $\mathrm{Rp}$ & $\mathrm{Rp}$ & $\mathrm{Rp}$ & \\
\hline \multicolumn{5}{|l|}{$\begin{array}{c}\text { Peralatan Kantor } \\
\text { Biaya }\end{array}$} \\
\hline \multirow{2}{*}{\multicolumn{5}{|c|}{$\begin{array}{l}\text { Perlengkapan } \\
\text { Kantor }\end{array}$}} \\
\hline & - & - & $5,200,000.00$ & \\
\hline \multirow[t]{2}{*}{ Biaya Listrik } & $\mathrm{Rp}$ & $\mathrm{Rp}$ & $\mathrm{Rp}$ & \\
\hline & $\begin{array}{c}2,200,000.00 \\
\text { Rp }\end{array}$ & $\begin{array}{c}1,200,000.00 \\
\text { Rp }\end{array}$ & $\begin{array}{c}1,000,000.00 \\
R p\end{array}$ & $30 \%$ \\
\hline Biaya Telp & $1,800,000.00$ & $1,000,000.00$ & $1,000,000.00$ & $22 \%$ \\
\hline \multirow[t]{2}{*}{ Biaya Internet } & $\mathrm{Rp}$ & $\mathrm{Rp}$ & $\mathrm{Rp}$ & \\
\hline & $3,600,000.00$ & $1,600,000.00$ & $1,000,000.00$ & $53 \%$ \\
\hline \multirow[t]{2}{*}{ Biaya VPS } & $\mathrm{Rp}$ & $\mathrm{Rp}$ & $\mathrm{Rp}$ & \\
\hline & $9,890,000.00$ & $2,700,000.00$ & $2,100,000.00$ & $68 \%$ \\
\hline Biaya Asuransi & $\mathrm{Rp}$ & $\mathrm{Rp}$ & $\mathrm{Rp}$ & \\
\hline $\begin{array}{c}\text { Pegawai } \\
\text { Biaya }\end{array}$ & $1,425,000.00$ & $638,000.00$ & $346,650.00$ & $60 \%$ \\
\hline Transportasi/Be & $\mathrm{Rp}$ & $\mathrm{Rp}$ & $\mathrm{Rp}$ & \\
\hline$n \sin$ & $2,200,000.00$ & $510,000.00$ & $450,000.00$ & $70 \%$ \\
\hline \multirow[t]{2}{*}{ Biaya Lain-Lain } & Rp & $\begin{array}{l}\mathrm{Rp} \\
\mathrm{A}\end{array}$ & $\mathrm{Rp}$ & \\
\hline & & 00 & $120,350.00$ & $05 \%$ \\
\hline
\end{tabular}




\begin{tabular}{|c|c|c|c|c|} 
Pajak (PPN) & $\mathrm{Rp}$ & $\mathrm{Rp}$ & $\mathrm{Rp}$ & \\
& $11,434,544.00$ & $5,980,844.00$ & $2,340,940.00$ & $70 \%$ \\
Pajak PPH Pasal & $\mathrm{Rp}$ & $\mathrm{Rp}$ & $\mathrm{Rp}$ & \\
23 & $1,314,434.00$ & $696,348.00$ & $401,740.00$ & $48 \%$ \\
Pajak PPH Pasal & $\mathrm{Rp}$ & $\mathrm{Rp}$ & & 676, \\
21 & $409,186.00$ & $267,600.00$ & - & 786 \\
Pajak PPH Final & $\mathrm{Rp}$ & & & \\
4 Ayat 2 & $1,100,500.00$ & - & - & \\
Total Beban & $\mathrm{Rp}$ & & $\mathrm{Rp}$ & \\
Usaha & $103,311,864.0$ & $\mathrm{Rp}$ & $\mathrm{Rp}$ & \\
\cline { 4 - 5 } Net Profit & 0 & $61,961,317.00$ & $50,864,577.00$ & $27 \%$ \\
\cline { 4 - 5 } & $11,213,136$ & $5,701,115$ & $-9,588,141$ & $-2 \%$ \\
\hline
\end{tabular}


Adapun data keuangan yang dianalisa adalah Pendapatan jasa Startup XYZ di tahun 2016 naik sebesar $40 \%$, begitu juga dengan pendapatan di luar usaha mengalami kenaikan sebesar 1,4\%, sehingga meningkatkan laba kotor sampai $40 \%$. Beban gaji pegawai meningkat hingga (35\%), disebabkan adanya perekrutan pegawai baru di Startup XYZ, sehingga meningkatkan beban usaha lainnya seperti biaya perlengkapan kantordan asuransi pegawai.

Kenaikan pendapatan Startup XYZ tentunya meningkatkan biaya pajak (PPN) sebesar 70\%, dan PPH Pasal 23 sebesar $48 \%$. Adanya biaya PPH Pasal 21 sebesar Rp 409,186 pada tahun 2016 disebabkan adanya gaji pegawai yang nilainya diatas batas Penghasilan Tidak Kena Pajak (PTKP).

Secara garis besar potensi Suluhbali.co cukup bagus, dan perusahaan mengalami pertumbuhan, di tandai dengan pendapatan yang di peroleh setiap tahun terdapat suatu keuntungan sehingga suluhbali.co merupakan mampu bersaing dengan kompetitornya.

Setelah mendapatkan hasil ,maka langkah selanjutnya adalah proyeksi laporan keuangan PT. XYZ. Proyeksi laporan keuangan merupakan bentuk perencanaan keuangan. Proyeksi juga akan memudahkan startup dan investor melihat apa yang akan terjadi berapa tahun yang akan datang. Semua perencanaan keuangan membutuhkan proyeksi penjualan karena penjualan atau pendapatan merupakan titik awal aktifitas perusahaan. Maka penting untuk mengetahui tingkat rata - rata pertumbuhan penjualan (sales growth). Compound AnnualGrowth Rate PT. XYZ yaitu:

Berikut adalah rumus dari Compound Annual Growth Rate yang akan di gunakan untuk mengetahui persentase kedepan Suluhbali.co.

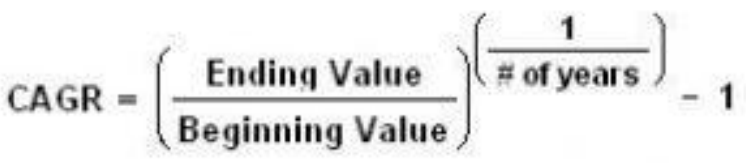

Dari laporan keuangan yang terlampir pada tabel di atas, persentase Compound Annual Growth Rate pada startup vokamo.com sebagai berikut :

$$
\begin{aligned}
\text { CAGR } & =\frac{(\operatorname{Rp~113,900,000.00)~}}{\operatorname{Rp~41,230,000.00~}}{ }^{\wedge}(1 / 3)-1 \\
& =40 \%
\end{aligned}
$$

Setelah di lakukan perhitungan menggunakan rumus Compound Annual Growth Rate maka di ketahui persentase laporan keuangan Suluhbali.co adalah $40 \%$. Dengan demikian di proyeksikan ke depan $40 \%$ agar laporan keuangan startup XY balance. 
Rumus perhitungan valuasi perusahaan PT. $\mathrm{XYZ}$ dengan menggunakan rumus present value adalah sebagai berikut:

$\mathrm{PV} \quad=$ (rate, rate pertumbuhan,total net profit)

$$
\begin{aligned}
= & \text { PV }(40 \%, 5, \text { Net Profit tahun } \\
& \text { pertama:Net Profit tahun kelima,0,0) } \\
= & \text { Rp 105,298,454.12 }
\end{aligned}
$$

Berdasarkan hasil perhitungan dari present value, estimasi nilai valuasi PT. XYZ dari faktor keuangan adalah sebesar $\mathrm{Rp}$ $105,298,454.12$

\section{Analisa Non Keuangan}

\section{1) Metode Scorecard Valuation}

Metode ini digunakan untuk membandingkan perusaaan sejenis pada tahap perkembangan yang sama (prerevenue perusahaan startups). Tahap pertama dalam metode ini adalah menentukan nilai rata-rata valuasi (premoney valuation) perusahaan sejenis. Pada kasus penelitian ini, tidak ditemukannya data nilai valuasi startup perusahaan sejenis lainnya sebagai pembanding. Maka dari itu, pendekatan nilai valuasi berdasarkan stage diperlukan, pendekatan ini sering digunakan oleh perusahaan venture capital dan angel investor untuk menilai sebuah startup. Mereka memiliki aturan mengenai nilai-nilai yang telah mereka tetapkan terhadap sebuah bisnis, tergantung pada di tahap mana startup itu berada. Semakin jauh perusahaan berkembang, risiko perusahaan lebih rendah, dan nilainya jadi lebih tinggi. Sebuah pendekatan Valuation

\begin{tabular}{|c|c|}
\hline Estimasi Nilai Valuasi & $\begin{array}{c}\text { Stage Of } \\
\text { Development }\end{array}$ \\
\hline $\begin{array}{l}\text { Rp 25.000.000 - } \\
\text { Rp.50.000.000 }\end{array}$ & $\begin{array}{l}\text { Aemiliki ide bisnis } \\
\text { tau rencana bisnis } \\
\text { yang menarik }\end{array}$ \\
\hline $\begin{array}{c}\mathrm{Rp} 50.000 .000-\mathrm{Rp} \\
100.000 .000\end{array}$ & $\begin{array}{l}\text { Memiliki } \\
\text { anajemen tim yang } \\
\text { kuat untuk } \\
\text { melaksanakan } \\
\text { rencana itu }\end{array}$ \\
\hline $\begin{array}{c}\mathrm{Rp} 100.000 .000-\mathrm{Rp} \\
200.000 .000\end{array}$ & $\begin{array}{l}\text { Memiliki produk } \\
\text { atau prototype }\end{array}$ \\
\hline $\begin{array}{c}\mathrm{Rp} 200.000 .000-\mathrm{Rp} \\
500.000 .000\end{array}$ & $\begin{array}{l}\text { Memiliki partner } \\
\text { rategis, atau tanda- } \\
\text { tanda basis } \\
\text { pelanggan. }\end{array}$ \\
\hline$>$ Rp 500.000.000 & $\begin{array}{l}\text { Memiliki tanda - } \\
\text { anda pertumbuhan } \\
\text { sndapatan dan jalur } \\
\text { rofitabilitas yang } \\
\text { jelas. }\end{array}$ \\
\hline
\end{tabular}
By Stage, terlihat seperti ini :

Tabel 8. Valuation Stage 
Tabel 9. Valuation Worksheet PT. XYZ

\begin{tabular}{|c|c|c|c|c|c|c|}
\hline NO & Factor & Impact & Score & $\begin{array}{c}\text { Total Score/ } \\
\text { jumlah indikator }\end{array}$ & Weighting & Factor \\
\hline 1 & \multicolumn{4}{|c|}{ Strength Of The Entrepreneur and Management Team } & & \\
\hline & \multicolumn{4}{|c|}{ Experience } & & \\
\hline & $\begin{array}{c}\text { Many years of business } \\
\text { experience }\end{array}$ & + & & \multirow[t]{7}{*}{$(7+0+7+6): 4=$} & \multirow[t]{7}{*}{$(5) \times 30 \%$} & \multirow[t]{19}{*}{1.5} \\
\hline & $\begin{array}{c}\text { Experience in this business } \\
\text { sector }\end{array}$ & ++ & & & & \\
\hline & Experience as a $\mathrm{CEO}$ & +++ & 7 & & & \\
\hline & $\begin{array}{c}\text { Experience as a } \mathrm{COO}, \\
\mathrm{CFO}, \mathrm{CTO}\end{array}$ & ++ & & & & \\
\hline & $\begin{array}{c}\text { Experience as a product } \\
\text { manager }\end{array}$ & + & & & & \\
\hline & $\begin{array}{c}\text { Experience in sales or } \\
\text { technology }\end{array}$ & - & & & & \\
\hline & No business experience & --- & & & & \\
\hline & \multicolumn{5}{|c|}{ Willing to step aside, if necessary, for an experienced CEO } & \\
\hline & Unwilling & --- & 0 & & & \\
\hline & Neutral & 0 & & & & \\
\hline & Willing & +++ & & & & \\
\hline & \multicolumn{5}{|c|}{ Is the founder coachable? } & \\
\hline & Yes & +++ & 7 & & & \\
\hline & No & --- & & & & \\
\hline & \multicolumn{5}{|c|}{ How complete is the management team? } & \\
\hline & Entrepreneur only & - & & & & \\
\hline & $\begin{array}{c}\text { One competent player in } \\
\text { place }\end{array}$ & 0 & & & & \\
\hline & $\begin{array}{c}\text { Team identified and on the } \\
\text { sideline }\end{array}$ & ++ & 6 & & & \\
\hline & Competent team in place & +++ & & & & \\
\hline 2 & \multicolumn{6}{|c|}{ Size Of the Opportunity } \\
\hline
\end{tabular}




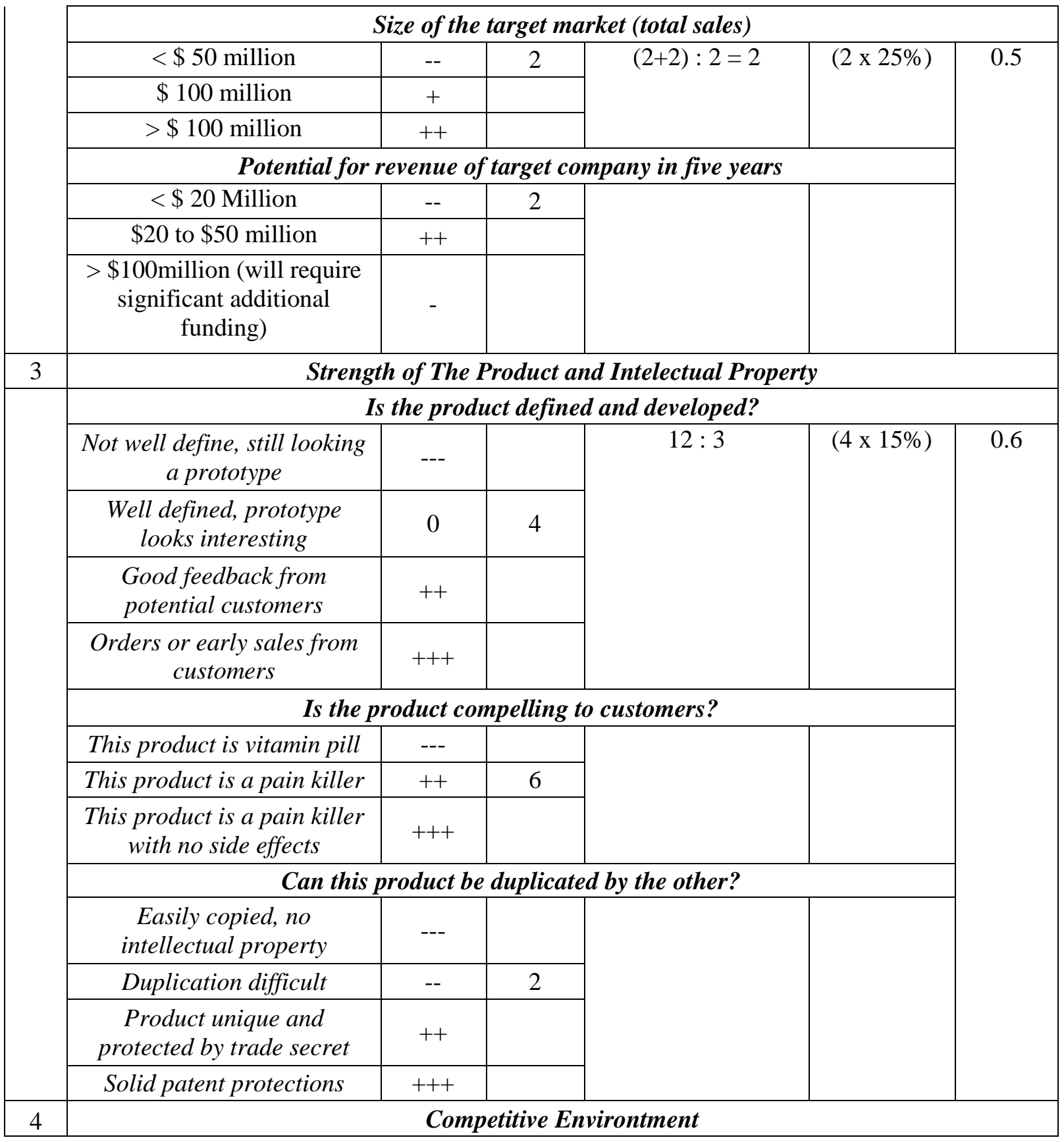




\begin{tabular}{|c|c|c|c|c|c|c|}
\hline & \multicolumn{6}{|c|}{ Streng of the competitors in this marketplace } \\
\hline & $\begin{array}{c}\text { Dominated by a single large } \\
\text { player }\end{array}$ & -- & & \multirow[t]{3}{*}{$3+4=5$} & \multirow[t]{3}{*}{$\left(4.5^{*} 10 \%\right)$} & \multirow[t]{3}{*}{0.45} \\
\hline & $\begin{array}{l}\text { Dominated by several } \\
\text { players }\end{array}$ & - & 3 & & & \\
\hline & $\begin{array}{c}\text { Fractured, many small } \\
\text { players }\end{array}$ & ++ & & & & \\
\hline & \multicolumn{6}{|c|}{ Strength of competitive products } \\
\hline & $\begin{array}{c}\text { Competitive products are } \\
\text { excellent }\end{array}$ & 0 & 4 & & & \\
\hline & $\begin{array}{c}\text { Competitive products are } \\
\text { weak }\end{array}$ & +++ & & & & \\
\hline 5 & \multicolumn{6}{|c|}{ Marketing,Sales,Partners } \\
\hline & \multicolumn{6}{|c|}{ Sales channels, sales and marketing partners } \\
\hline & $\begin{array}{l}\text { Haven't even discussed } \\
\text { sales channels }\end{array}$ & --- & & \multirow[t]{5}{*}{7} & \multirow[t]{5}{*}{$7 \times 10 \%$} & \multirow[t]{5}{*}{0.7} \\
\hline & $\begin{array}{c}\text { Key beta testers identified } \\
\text { and contacted }\end{array}$ & ++ & & & & \\
\hline & $\begin{array}{c}\text { Channels secure, customers } \\
\text { placed trial orders }\end{array}$ & +++ & 7 & & & \\
\hline & No partners identified & -- & & & & \\
\hline & Key partners in place & ++ & & & & \\
\hline 6 & \multicolumn{6}{|c|}{ Other } \\
\hline & \multicolumn{6}{|c|}{ Need for additional rounds of funding } \\
\hline & None & +++ & & \multirow{2}{*}{$10: 2=5$} & \multirow{2}{*}{$5 \times 10 \%$} & \multirow[t]{2}{*}{0.5} \\
\hline & Another Angel Round & 0 & 4 & & & \\
\hline
\end{tabular}




\begin{tabular}{|c|c|c|c|r|c|}
\hline Another Venture Capital & -- & & & \\
\hline & & & & \\
& Positive other factors & ++ & 6 & & \\
& Negative other factors & -- & & & \\
\hline
\end{tabular}


Berdasarkan competitor dari startup XYZ yaitu Balipost.com, Nusabali.com dan Metrobaali.com berada pada stage dimana sudah memiliki tanda tanda pertumbuhan pendapatan dan jalur profitabilitas yang jelas, sehingga estimasi nilai valuasi adalah Rp. 500.000.000, sehingga tahap akhir metode scorecard valuation :

Valuation $=$ Average pre-money valuation of companies * Extension SUM of Valuation Worksheet

Valuation $=\operatorname{Rp} 500.000 .000 \times 4,25$

$$
=\text { Rp.2.125.000.000,- }
$$

Berdasarkan hasil observasi dari valuation worksheet, estimasi nilai valuasi startup XYZ dari faktor non keuangan adalah sebesar Rp.2.125.000.000,-

\section{SIMPULAN DAN SARAN}

1. Analisa komparatif laporan Laba/Rugi Suluhbali.co 3 tahun. Dalam laporan Laba/Rugi startup XYZ terdapat total income startup XYZ mendapat suatu keuntungan/profit Rp. 2.230.298.454 sehingga akan balance dengan biaya/expenses.

2. Rasio pertumbuhan Compound Annual Growth Rate yang akan di gunakan untuk mengetahui persentase kedepan startup XYZ. Dari laporan keuangan yang terlampir pada tabel di atas, persentase Compound Annual Growth Rate pada startup startup XYZ adalah $40 \%$. Dengan demikian di proyeksikan ke depan $40 \%$ hingga mencapai proyeksi tahun ke 5.

3. Perhitungan nilai valuasi startup XYZ menggunakan metode Analisis Data Keuangan melalui Analisis Laporan Keuangan Komparatif (Comparative Financial Statement Analysis) dan metode Scalling Stage Projeksi Laporan Keuangan dan Analisis Data Non Keuangan melalui Metode Scorecard
Valuation (pre-revenue perusahaan startups) dan Valuation Worksheet (qualitative content analysis).

4. Hasil analisa faktor keuangan dan faktor non keuangan dengan menggunakan metode Analisis Data Kuantitatif melalui Analisis Laporan Keuangan Komparatif (Comparative Financial Statement Analysis) adalah sebesar Rp. 105.298.454.12,- kemudian hasil analisa faktor non keuangan dengan menggunakan metode Scorecard Valuation (pre-revenue perusahaan startups) dan Valuation Worksheet (qualitative content analysis) adalah sebesar Rp.2.125.000.000,-. Dengan demikian nilai valuasi startup startup XYZ adalah menjumlahkan nilai keunagan dan non keuangan yaitu sebesar Rp. 2.230.298.454

\subsection{Saran}

Beberapa saran yang dapat penulis sampaikan untuk perusahaan startup $\mathrm{XYZ}$ antara lain :

1. Berdasarkan penelitian selanjutnya diharapkan lebih menekankan dan membahan tentang factor non keuangan yang mempengaruhi nilai valuasi startup.

2. Hasil penelitian ini diharapkan dapat dijadikan sebagai bahan rujukan bagi penelitian selanjutnya. Untuk penelitian valuasi perusahaan startup dapat juga di lakukan dengan metode scorecard.

\section{DAFTAR PUSTAKA}

[1]Asosiasi Penyelenggara Jasa Internet Indonesia (APJII).2016. Infografis Penetrasi Dan Perilaku Pengguna Internet Indonesia. Jakarta: APJII.survei@apjii.or.id. Diakses tanggal 5 Februari 2017.

[3]Anonim.2014https://www.romelteamedia.com/ 2014/04/media-online-pengertian-dan.html

[4]Susmita,Tri.2015.http://eprints.polsri.ac.id/2654 /3/BAB\%20II.pdf. Diakses 1 Januari 2019

[8]Pratama, Aditya Hadi.2018.

https://id.techinasia.com/valuasi-startup- 
pengertian-cara-hitung. Diakses 7 Februari 2019

[9]Puspitaningtyas, Zarah. 2013. Perilaku Investor Dalam Pengambilan Keputusan Investasi Di Pasar Modal. Pontianak: Conference Paper, Forum Manajemen Indonesia Ke-5, 2013. https://www.researchgate.net/publication/25 9392260_PERILAKU_INVESTOR_DALA M PENGAMBILAN KEPUTUSAN INV ESTASI_DI_PASAR_MODAL. Diakses 3 Maret 2017.

[12]Fridayanti, Ni Putu Okta. 2016. Valuasi Perusahaan Berdasarkan Data Keuangan dan Non Keuangan: Studi kasus pada PT. Berita Bali Media (Skripsi). Bali: STMIK Primakara.

[13] Sitepu, Sri Nathasia Br. 2015. Pengaruh Faktor Keuangan Dan Non-Keuangan Mencapai Keberhasilan Startup Bisnis. DeReMa Jurnal Manajemen Vol.10, No. 2, hal. $285-$ 299. <http://ojs.uph.edu/index.php/DJM/arti cle/view/163>. Diakses 5 Februari 2017.

[14]Haryanti, Caecilia Sri. 2015. Analisis
Perbandingan Laporan Keuangan Untuk Menilai Kinerja Keuangan Pada Perusahaan Telekomunikasi (Studi Kasus BEI). Serat Acitya Jurnal Ilmiah UNTAG Semarang, hal-86.

<https://jurnal.untagsmg.ac.id/index.php/sa/ article/viewFile/154/212>. Diakses 5 Maret 2017.

[15]Noerirawan, Moch. Ronni dan Abdul Muid. 2012. Pengaruh Faktor Internal dan Eksternal Perusahaan Terhadap Nilai Perusahaan (Studi Empiris Pada Perusahaan Manufaktur yang Terdaftar di Bursa Efek Indonesia Periode 2007-2010). Diponegoro Journal Of Accounting, Vol.1,No.2,hal:112.

[17]Payne, William H. (Bill). 2011.The Definitive Guide to Raising Money From Angels. United States: Bill Payne \& Associates. $<$ http://s3.amazonaws.com/angelsoft-as2appr/collateral/2011-09$12+$ Definitive+Guide+Raising+Money+fro m+Angels.pdf >. Diakses 1 Juni 2017. 